\title{
Absence of high red blood cell velocity in the sublingual microcirculation of patients with hyerdynamic septic shock
}

\author{
VS Kanoore Edul ${ }^{1,2^{*}}$, C Ince $^{2}$, A Risso Vazquez ${ }^{3}$, PN Rubatto ${ }^{3}$, ED Valenzuela Espinoza ${ }^{3}$, S Welsh $^{3}$, C Enrico ${ }^{3}$, \\ A Dubin ${ }^{3}$
}

From ESICM LIVES 2015

Berlin, Germany. 3-7 October 2015

\section{Introduction}

A quantitative assessment of the microcirculation in patients with septic shock previously found that microvascular flow and red blood cell (RBC) velocity were decreased ${ }^{1}$. This study, however, mainly included patients with normodynamic septic shock.

\section{Objectives}

To show the presence of increased RBCV velocity in the sublingual microcirculation of patients with hyperdynamic septic shock.

\section{Methods}

We evaluated the sublingual microcirculation of patients with hyperdynamic $(\mathrm{n}=20)$ and normodynamic $(\mathrm{n}=20)$ septic shock, and in healthy volunteers $(\mathrm{n}=20)$. We defined hyperdynamic septic shock as a cardiac index > $4.0 \mathrm{~L} / \mathrm{min} / \mathrm{m}^{2}$. Videos were acquired with a SDF-imaging device and analyzed with the AVA 3.0 software. Microvascular variables were compared with one-way ANOVA. Histograms of RBC velocities were built.

\section{Results}

The perfused vascular density $(14.7 \pm 4.4,14.1 \pm 3.9,17.4$ $\left.\pm 1.1 \mathrm{~mm} / \mathrm{mm}^{2}, P<0.05\right)$, the proportion of perfused vessels, $(0.84 \pm 0.24,0.85 \pm 0.23,1.00 \pm 0.00, P<0.0001)$, the microvascular flow index $(2.4 \pm 0.7,2.4 \pm 0.7,3.0 \pm$ $0.0, P<0.0001)$, and the RBC velocity $(912 \pm 291,968 \pm$ $204,1303 \pm 120 \mu \mathrm{m} / \mathrm{s}, P<0.0001)$ were similar in hyperdynamic and normodynamic septic shock, but lower than in healthy volunteers. Both hyperdynamic and

${ }^{1}$ Hospital Fernández, Servicio de Terapia Intensiva, Buenos Aires, Argentina Full list of author information is available at the end of the article normodynamic septic shock did not have small microvessels with RBC velocity higher than the percentile 1.0 of the healthy volunteers.

\section{Conclusions}

As occurred in normodynamic septic shock, high RBC velocity was absent in the sublingual microcirculation of patients with hyperdynamic septic shock. Moreover, the histograms of septic patients were shifted to the low range of RBC velocity.

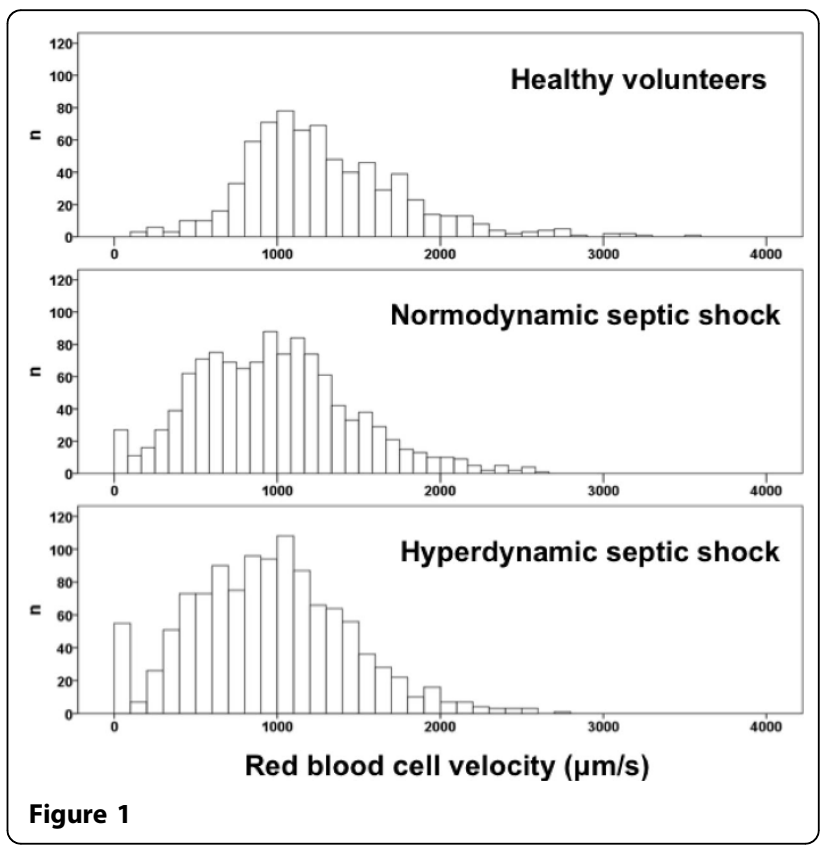

(c) 2015 Kanoore Edul et al.; This is an Open Access article distributed under the terms of the Creative Commons Attribution License (http://creativecommons.org/licenses/by/4.0), which permits unrestricted use, distribution, and reproduction in any medium, provided the original work is properly cited. 


\section{Grant Acknowledgment}

Supported by the grant PICT-2010-00495, Agencia Nacional de Promoción Científica y Tecnológica, Argentina.

\section{Authors' details}

'Hospital Fernández, Servicio de Terapia Intensiva, Buenos Aires, Argentina.

${ }^{2}$ Academic Medical Center, University of Amsterdam, Translational

Physiology, Amsterdam, the Netherlands. ${ }^{3}$ Sanatorio Otamendi y Miroli,

Servicio de Terapia Intensiva, Buenos Aires, Argentina.

Published: 1 October 2015

\section{Reference}

1. Edul VS, Enrico C, Laviolle B, Vazquez AR, Ince C, Dubin A: Quantitative assessment of the microcirculation in healthy volunteers and in patients with septic shock. Crit Care Med 2012, 40(5):1443-1448.

doi:10.1186/2197-425X-3-S1-A412

Cite this article as: Kanoore Edul et al: Absence of high red blood cell velocity in the sublingual microcirculation of patients with hyerdynamic septic shock. Intensive Care Medicine Experimental 2015 3(Suppl 1):A412.

\section{Submit your manuscript to a SpringerOpen ${ }^{\mathcal{O}}$ journal and benefit from:}

- Convenient online submission

- Rigorous peer review

- Immediate publication on acceptance

- Open access: articles freely available online

- High visibility within the field

- Retaining the copyright to your article 